(С С.Ф. Юхимчук, к.т.н., Л.М. Дацюк, к.т.н., М.М. Толстушко, к.т.н. Луцький національний технічний університет

\title{
РОЗРОБКА СІВАЛКИ ТОЧНОГО ВИСІВУ ДЛЯ ПРЯМОГО СІВУ ЦУКРОВОГО БУРЯКА
}

У статті обтрунтовано дочільність прямого сіву иукрового буряка та запропоновано конструкиію сівалки точного висіву, яка призначена для прямого сіву каліброваного насіння иукрового буряка і наведено ї̈ основні параметри.

Постановка проблеми. В умовах ринку все більше використовуються грунтозахисні та енергозберігальні технології обробітку грунту, зокрема система мінімального обробітку грунту та іiі різновид - прямий сів. Аналіз відомих закордонних та вітчизняних сівалок прямого сіву показав, що кожна з них при своїх перевагах і недоліках у повній мірі не забезпечує необхідної за агровимогами рівномірності загортання насіння на глибину $[1,2]$.

У 80-ті роки в країнах Західної Європи почали сіяти цукровий буряк по мульчі, отриманої після збирання проміжної культури (фацелія, гірчиця і ін.). Але вже в 90-х рр. цукрові буряки стали сіяти по солом'яній мульчі (технологія Strip-Till).

Безпосередньо перед сівбою деякі господарства не проводять обробку грунту. Це дозволяє краще зберегти шар мульчі, a 3 ним і всі переваги використання мульчі. Але це вимагає оснащення сівалок спеціальним обладнанням, яке забезпечує проведення прямого сіву.

Частина господарств, у яких площі посіву менш еродовані, проводять весняну підготовку грунту на глибину 4-5 см за допомогою компакторів.

Для підгодівлі використовують некореневі добрива. Боротьбу 3 бур'янами проводять за загальноприйнятими гербіцидними технологіями. 
Аналіз останніх досліджень і публікацій. Досвід вирощування цукрового буряка 3 використанням солом'яної мульчі описаний в роботах фахівців з Німеччини (J. Brunotte, M. Joschko, H. Rogasik, 1998; Werner Kropf, 2001; Clemens Becker, 2001; Rudolf Merkes, 2001; K. Erhard, 2002) . Отримані ними дані показують, що:

1. Грунт краще захищена від водної та вітрової ерозії, а також від непродуктивного випаровування вологи, утворення кірки і замулювання. Завдяки такому способу сівби вдається отримати стабільну врожайність (40-50 т/га) при випаданні в середньому менше 500 мм опадів (20\% років - менше 400 мм) в рік.

Господарства, розташовані в горбистій місцевості застосовуючи солом'яну мульчу, отримують високі та надійні врожаї коренеплодів.

2. Підвищується біологічна активність грунту, про що свідчить збільшення числа дощових черв'яків, які мають велике функціональне значення для екосистеми грунту, так як сприяють утворенню структури грунту, росту і розвитку рослин.

3. Мульчуючий спосіб обробітку, завдяки легкому розпушуванню залишків рослин на поверхні, являє концепцію обробки, яка реалізує і захист грунту, і економію коштів.

Висока ефективність технології підтверджується зростанням площ, зайнятих в Німеччині цукровими буряками, на яких застосовують посів у солом'яну мульчу (технологія Strip-Till). Обробіток цукрового буряка в рамках успішно випробовується на випробувальній станції Інгер Хоф з 2007 року. Вже 75\% полів, зайнятих цукровими буряками, засіваються за технологією StripTill.

Iз наведеного вище матеріалу, можна зробити висновок про актуальність прямого сіву насіння цукрового буряка. Також варто зазначити, що існуючі конструкції сошників для прямого сіву нарізають у грунті борозни, у які з певним інтервалом вкладаються насіннини, що чинить тяговий опір. Тому важливим $є$ зниження енергозатрат процесу посіву за рахунок розробки таких робочих органів, які б робили не суцільну борозну, а лунки під кожну насіннину окремо. Це можна досягнути запропонувавши принципово нову конструкцію сівалки точного висіву. Схема цієї сівалки була запатентована нами [3] i було графічним та математичним способами визначено форму вітки направляючої, яка працює по принципу мальтійського механізму [4]. На основі цього була розроблена конструкція сівалки точного висіву, яка призначена для прямого сіву каліброваного насіння цукрового буряка і обгрунтовано іiї основні параметри. 
Мета дослідження. Метою даної роботи $\epsilon$ зниження енергозатрат, зменшення витрат насіннєвого матеріалу на основі обгрунтування параметрів нової сівалки точного висіву, призначеної для прямого сіву каліброваного насіння цукрового буряка.

Результати дослідження. Головна відмінність розробленої конструкції сівалки від раніше існуючих в тому, що кожна висіяна насінина попадає в окрему ямку в грунті, яка приготовлена спеціальним робочим органом.

Даним робочим органом, який утворює в грунті ямки i подає в них насінини, є зуб-сошник (рис. 1). Він являє собою звужену на кінці трубку 1, в якій рухається стержень 2. Зубисошники шарнірно кріпляться на ланцюгу 3 певним сталим інтервалом один від одного. При входженні зуба-сошника в грунт стержень 2 займає своє нижнє положення (поз. А). Зверху в канал вертикально заглибленого в грунт зуба-сошника попадає насінина, яка вільно падає. Одночасно стержень 2 починає підніматись аж поки не займе верхнього положення (поз. Б) і не відкриє насінині доступ до попадання в утворене у грунті заглиблення.

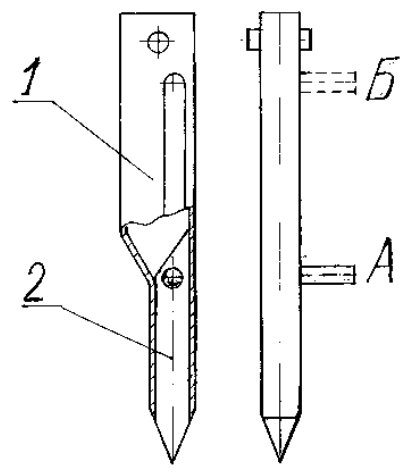

Рис. 1 - Зуб-сошник

Конструкція сівалки точного висіву (рис. 2) включає: 1 привідне колесо; 2 - пасову передачу; 3 - ведучу зірочку; 4 - штирі; 5 - направляючу; 6 - ланцюг; 7 - зуби-сошники; 8 - рухомі стержні зубів-сошників; 9 - конічну шестерню; 10 - нижній шків; 11 транспортер насінин; 12 і 13 - направляючі планки; 14 - очисникзагортач; 15 - натяжну зірочку; 16 - бункер для насіння; 17 - щиток; 18 - зубчасто-пасову передачу. Ланцюгова передача працює за принципом гусениці, тобто, ведуча 3 i натяжна 15 зірочки 
перекочуються по ланцюгу 6. Це значить, що ланки ланцюга в нижній частині ланцюгової передачі нерухомі відносно поверхні грунту. А отже, зуби-сошники 7 заглиблені в грунт весь час, необхідний для проходження насінин від висіваючого апарату до ямок в грунті.

Для того, щоб під час заглиблення зуба-сошника 7 стержень 8 займав своє крайнє нижнє положення і зуб-сошник 7 входив у грунт вертикально, служить направляюча 5, яка приводитьсь в рух від штирів 4, що жорстко закріплені на бічній поверхні привідної зірочки 3.

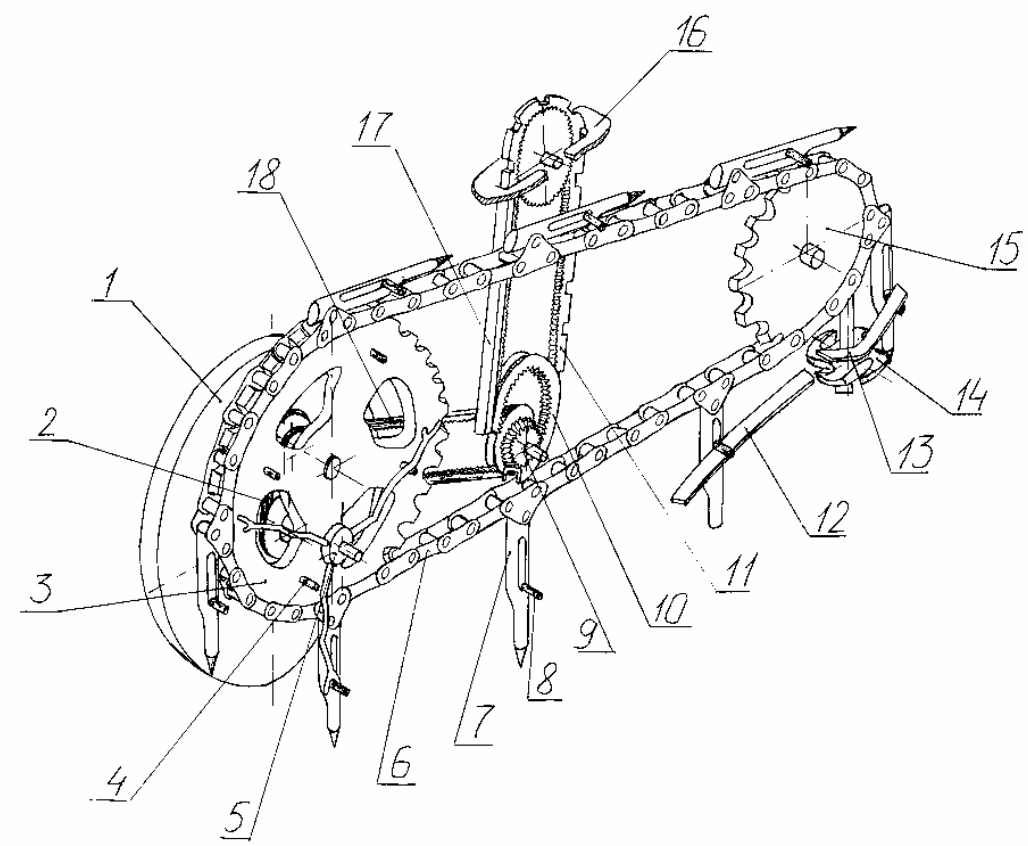

Рис. 2 - Схема сівалки точного висіву

Принцип роботи сівалки наступний. При русі агрегату колесо 1 контактуючи 3 поверхнею землі обертається i через зубчасту передачу 2 приводить в рух ведучу зірочку 3. Завдяки контакту з штирями 4 повертається направляюча 5. Один кінець якої вступає в контакт з стержнем 8 зуба-сошника 7, приводячи його в крайнє нижнє положення. При цьому, по мірі того, як ведуча 
зірочка 3 накочується на ланцюг 6, зуб-сошник 7 починає заглиблюватись в грунт на певну глибину і займає вертикальне положення. Дальше при русі агрегату до зуба-сошника 7 наближається висіваючий апарат, який являє собою зубчастопасову передачу. В цій передачі зубчастий пас являється також i транспортером насіння 11 (на пасі зроблені спеціальні комірки для насінин), а нижній шків $10 €$ одночасно і зубчастим колесом зубчастої конічної 3 внутрішнім зачепленням передачі. Привід висіваючого апарату забезпечує зубчасто-пасова передача 18, ведучий шків якої жорстко закріплений на валу ведучої зірочки 3 , а ведений - жорстко з'єднаний з конічною шестернею 9. Насіння захвачується транспортером 11 у бункері 16. Для запобігання випаданню насінин при транспортуванні служить щиток 17. При наближенні до заглибленого в грунт зуба-сошника 7 зисіваючого апарату, а саме 3 комірки транспортера 11, випадає насінина, яка попадає прямо в канал зуба-сошника 7.

Дальше при русі агрегату, до заглибленого в грунт зубасошника 7 наближається піднімальна планка 12. Контактуючи 3 якою, стержень 8 піднімається до крайнього верхнього положення і відкриває доступ насінині до грунту. Дальше ланцюг починає намотуватись на натяжну зірочку 15 і зуб-сошник 7 виймається 3 грунту: стержень 8, взаємодіючи з направляючою пластиною 13, опускається у нижнє положення: зуб-сошник 7 очищується від залишків грунту спеціальним очисником-загортачем 14 , який також загортає насіння.

Секції сівалки кріпляться на рамі шарнірно, що дає змогу добре копіювати рел'єф поля.

Кінематична схема сівалки наведена на рис. 3.. Привод робочих органів здійснюється від опорно-приводного колеса. Щоб передати однакову кутову швидкість від приводного колеса до ведучої зірочки ланцюгової передачі використаємо циліндричну зубчату прямозубу евольвентну передачу зовнішнього зачеплення. Проміжна шестірня потрібна для того, щоб ведуча шестірня i колесо обертались в одну сторону .

Модуль цієї передачі $m=2$, число зубів шестірні і колеса $Z=40$, число зубів проміжної шестерні буде : $Z=20$.

Дальше нам потрібно передати крутний момент на привід висіваючого апарату. Для цього ми використовуємо зубчату пасову передачу .

Ведучий шків цієї передачі жорстко зв'язаний з ведучою зірочкою ланцюгової передачі і обертається 3 однаковою 3 нею 
кутовою швидкістю. Параметри цієї передачі: модуль передачі $m=3$; число зубів ведучого і веденого шківів $z=23$.

Ведений шків жорстко закріплений на нижньому валу висіваючого апарата і надає йому крутний момент, потрібний для приводу висіваючого апарата. Висіваючий апарат повинен бути відхилений від площини , в якій розміщена ланцюгова передача на кут $\varphi=7^{\circ}$. Для цього використано зубчасту конічну прямозубу евольвентну 3 внутрішнім зачеплення передачу. Параметри цієї передачі наступні: модуль $m=2$, кількість зубів шестірні - 17, а колеса - 55.

Транспортер насіння являе собою зубчасто-пасову передачу, в якій зубчастий пас являє собою також пас з гніздами для насіння. Колесо циліндричної внутрішньої передачі являє собою також ведучий шків цієї передачі. Ведений шків цієї передачі має такі самі розміри, що і ведучий, а саме модуль -3 , і кількість зубів -47 .

Зуби-сошники шарнірно закріплені на ланцюзі ПРД-38,12950 ГОСТ 13568-75. Ведуча і ведена зірочки однакових розмірів, мають 24 зуба.

Щоб передати однакову кутову швидкість від приводного колеса до ведучої зірочки ланцюгової передачі використаємо циліндричну зубчату прямозубу евольвентну передачу зовнішнього зачеплення. Проміжна шестірня потрібна для того, щоб ведуча шестірня і колесо обертались в одну сторону.

Дальше нам потрібно передати крутний момент на привід висіваючого апарату. Для цього ми використовуємо зубчату пасову передачу .

Ведучий шків цієї передачі жорстко зв'язаний з ведучою зірочкою ланцюгової передачі і обертається 3 однаковою 3 нею кутовою швидкістю .

Ведений шків жорстко закріплений на нижньому валу висіваючого апарата і надає йому крутний момент, потрібний для приводу висіваючого апарата. Висіваючий апарат повинен бути відхилений від площини , в якій розміщена ланцюгова передача на кут $7^{\circ}$. Для цього використано зубчасту конічну прямозубу евольвентну з внутрішнім зачеплення передачу. 

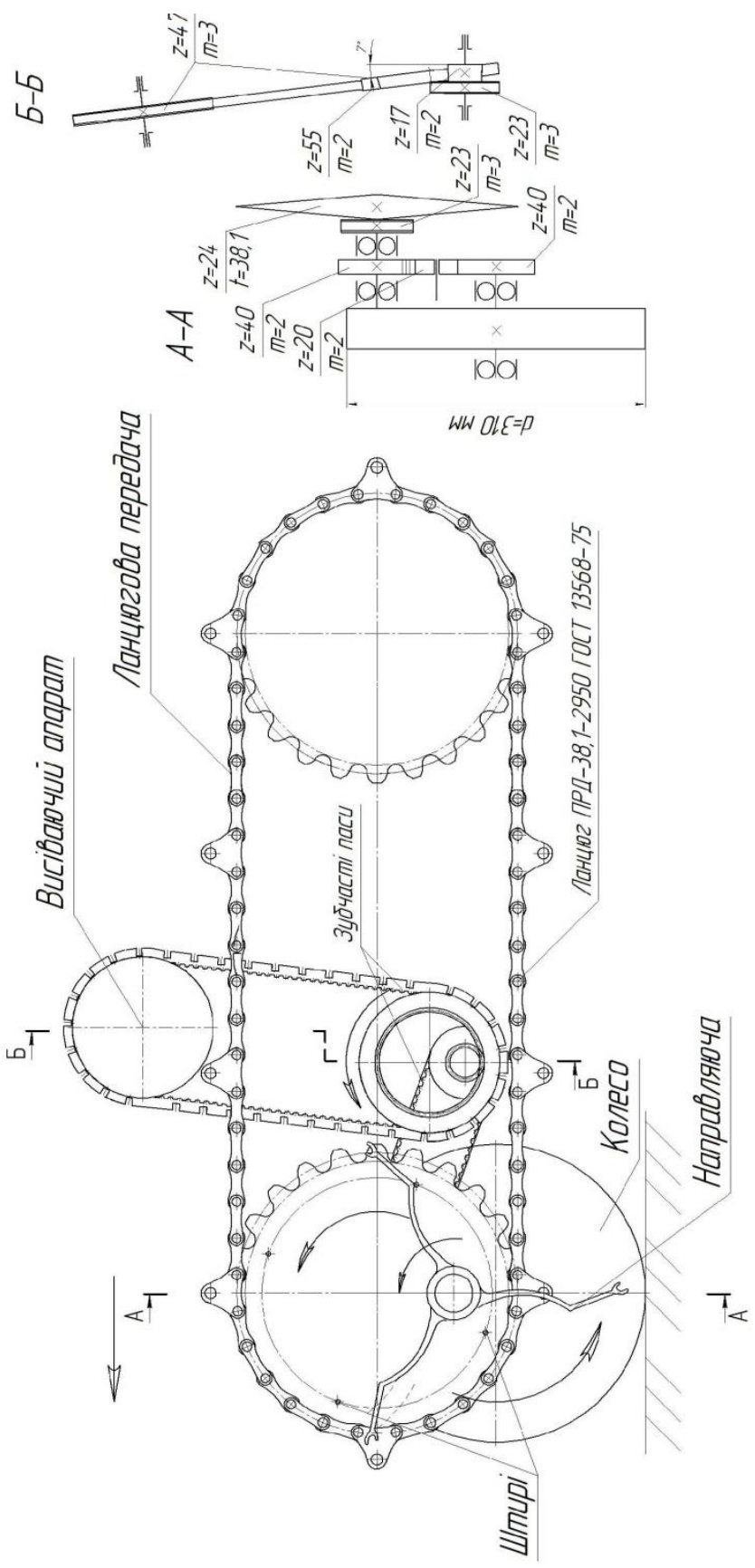

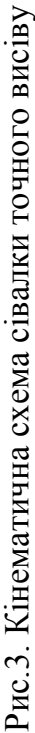


Транспортер насіння являє собою зубчасто-пасову передачу, в якій зубчастий пас являє собою також пас з гніздами для насіння. Колесо циліндричної внутрішньої передачі являє собою також ведучий шків цієї передачі.

Зуби-сошники шарнірно закріплені на ланцюзі. Ведуча i ведена зірочки однакових розмірів. Привід направляючої забезпечується штирями, розміщеними на ведучій зірочці.

За аналог сівалки була взята бурякова сівалка ССТ -12 А. На основі цього розроблена принципова схема сівалки точного висіву, призначена для сіву каліброваного насіння цукрового буряка на 12 рядках, з такою технічною характеристикою::

1. Тип машини - навісна.

2. Агрегатування - трактор Т-25.

3. Робоча швидкість - до 8 км/год.

4. Глибина зароблення насіння - 30-35 мм.

5. Норм висіву насіння - 4 шт. на метр рядка.

6. Ширина міжрядь - $40 \ldots 60 \mathrm{~cm}$.

7. Ширина захвату - 4,8...7,2 м.

Висновки. На основі і теоретичних досліджень сівалки було визначено:

- продуктивність сівалки при ширині міжрядь 45 см - 4,3 га/год;

- потужність, яку витрачає трактор при роботі з сівалкою склала 8,3 кВт;

- $\quad$ відстань між зубами-сошниками на ланцюзі рівна 23 см;

- ділильний діаметр ведучої і натяжної зірочок ланцюгової передачі 289 мм, міжосьова відстань в ланцюговій передачі - 68 см; від моменту випадання насінини з висіваючого апарату до моменту початку виймання зуба-сошника з грунту, машина пройде $48 \mathrm{~cm}$, або проекція на горизонталь відстані від центру нижнього шківа висіваючого апарата до центру натяжки зірочки рівна 48 см;

- об'єм одного бункера для насіння - 8 л, однієї заправки бункера насінням хватає на 16 км, або на 2 години роботи; $\mathrm{c}^{-1}$;

- кутова швидкість ведучої зірочки ланцюгової передачі - 12,57

- $\quad$ реальний радіус приводного колеса - 170 мм;

- швидкість руху транспортера насіння - 0,27 м/с, число гнізд на зубчастому пасі - 37, параметри гнізда: 7х7x5 мм;

- габаритні розміри сівалки при ширині захвату 5,4 м склали: висота - 1,05 м і довжина - 1,15 м. 


\section{Література}

1. Гассен Д. Прямой посев - дорога в будущее / Д. Гассен, Ф. Гассен.- Днепропетровск: Корпорація "Агро-Союз", 2004.- 206 с.

2. Ресурсозберігаючі технології механічного обробітку грунту в сучасному землеробстві України / [І.Д. Примак, В.О. Сщенко, Ю.П. Манько та ін.]; за ред. І.Д. Примака.- К.: „КВІЦ““, 2007.- 272 с.

3. Пат. 9676А України, МКл А01С7/18. Сівалка точного висіву / С.Ф. Юхимчук (Україна) - № 94022735. Заявл. 10.02.94. Опубл. 30.09.96. Бюл. № 3.

4. Юхимчук С.Ф., Синій С.В., Гошко 3.О. Визначення форми направляючої нової сівалки точного висіву // Вісник Харківського державного технічного університету сільського господарства "Механізація сільськогосподарського виробництва". Вип. 1.-Харків: ХДТУСГ, 2000. - С. 334-341. 